Atmos. Chem. Phys., 13, 2321-2330, 2013

www.atmos-chem-phys.net/13/2321/2013/

doi:10.5194/acp-13-2321-2013

(C) Author(s) 2013. CC Attribution 3.0 License.

\title{
Dynamics of the chemical composition of rainwater throughout Hurricane Irene
}

\author{
K. M. Mullaugh ${ }^{1}{ }^{*}$, J. D. Willey ${ }^{1}$, R. J. Kieber ${ }^{1}$, R. N. Mead $^{1}$, and G. B. Avery Jr. ${ }^{1}$ \\ ${ }^{1}$ Department of Chemistry and Biochemistry, University of North Carolina Wilmington, Wilmington, NC 28403-5932, USA \\ *now at: Chemistry Department, Elon University, Elon, NC 27244, USA
}

Correspondence to: K. M. Mullaugh (kmullaugh@elon.edu)

Received: 6 July 2012 - Published in Atmos. Chem. Phys. Discuss.: 15 October 2012

Revised: 17 January 2013 - Accepted: 6 February 2013 - Published: 1 March 2013

\begin{abstract}
Sequential sampling of rainwater from Hurricane Irene was carried out in Wilmington, NC, USA on 26 and 27 August 2011. Eleven samples were analyzed for $\mathrm{pH}$, major ions $\left(\mathrm{Cl}^{-}, \mathrm{NO}_{3}^{-}, \mathrm{SO}_{4}^{2-}, \mathrm{Na}^{+}, \mathrm{K}^{+}, \mathrm{Mg}^{2+}, \mathrm{Ca}^{2+}, \mathrm{NH}_{4}^{+}\right)$, dissolved organic carbon (DOC) and hydrogen peroxide $\left(\mathrm{H}_{2} \mathrm{O}_{2}\right)$. Hurricane Irene contributed $16 \%$ of the total rainwater and $18 \%$ of the total chloride wet deposition received in Wilmington NC during all of 2011. This work highlights the main physical factors influencing the chemical composition of tropical storm rainwater: wind speed, wind direction, back trajectory and vertical mixing, time of day and total rain volume. Samples collected early in the storm, when winds blew out of the east, contained dissolved components indicative of marine sources (salts from sea spray and low DOC). The sea-salt components in the samples had two maxima in concentration during the storm the first of which occurred before the volume of rain had sufficiently washed out sea salt from the atmosphere and the second when back trajectories showed large volumes of marine surface air were lifted. As the storm progressed and winds shifted to a westerly direction, the chemical composition of the rainwater became characteristic of terrestrial storms (high DOC and $\mathrm{NH}_{4}^{+}$and low sea salt). This work demonstrates that tropical storms are not only responsible for significant wet deposition of marine components to land, but terrestrial components can also become entrained in rainwater, which can then be delivered to coastal waters via wet deposition. This study also underscores why analysis of one composite sample can lead to an incomplete interpretation of the factors that influence the chemically divergent analytes in rainwater during extreme weather events.
\end{abstract}

\section{Introduction}

Extreme weather events that include heavy rain and high winds can result in significant depositional fluxes of chemical species over short periods of time, resulting in a significant impact on the biogeochemistry of the receiving watersheds (Avery et al., 2004). Most notably, tropical storm systems have been shown to be responsible for major depositions of sea salt $\left(\mathrm{Na}^{+}\right.$and $\left.\mathrm{Cl}^{-}\right)$to land. Previous work at this site (Wilmington, NC, USA) has shown that single tropical weather events contributed over half the annual wet deposition of chloride $\left(\mathrm{Cl}^{-}\right)$in 1984, 1989 (Willey and Kiefer, 1993) and 2006 (Miller et al., 2008). Similarly, the elemental analysis of rainwater collected during typhoon events in Okinawa Island, Japan revealed ion ratios consistent with the composition of sea salt (Sakihama and Tokuyama, 2005). The isotopic analysis of DOC in rainwater collected during two hurricanes revealed it was largely of marine origin (Raymond, 2005).

In addition to the deposition of marine-derived components to land as a result of hurricanes and typhoons, shifting winds during the course of a storm could result in delivery of terrestrial compounds to coastal waters via wet deposition. For example, previous work at this site during Hurricane Isabel in 2003 showed high ammonium $\left(\mathrm{NH}_{4}^{+}\right)$and amino acid concentrations when the back trajectory coincided with a region with an active animal agricultural industry (Kieber et al., 2005). High fluxes of heavy metals from anthropogenic sources have been reported in precipitation from typhoons in Taiwan (Cheng and You, 2010). Additionally, the DOC in rainwater is more bioavailable than river water (Avery et al., 2003), suggesting hurricanes can contribute significantly

Published by Copernicus Publications on behalf of the European Geosciences Union. 
to the annual flux of bioavailable DOC (Avery et al., 2004). These large depositional events have significant implications for coastal waters that may be sensitive to the deposition of nutrients (Kieber et al., 2005; Avery et al., 2004) and pollutants (Cheng and You, 2010) from terrestrial sources.

The degree to which various meterological factors (wind speed, direction and air parcel elevation) control the chemical composition of rainwater throughout a tropical precipitation event remains uncertain. Previous studies were of partial analytical scope (Kieber et al., 2005), had limited shifts in back trajectories (Miller et al., 2008) or did not aim to sample with enough temporal resolution to demonstrate how changes in wind direction influence the chemical composition of rainwater throughout a single tropical event (Cheng and You, 2010). The goal of the present study was to carry out a suite of chemical analyses on analytes coming from different sources on samples collected with high temporal resolution throughout a single tropical storm event so that the effects of a dynamic weather system could be assessed. Our coastal location is an ideal place to carry out such a study in which it is necessary to delineate marine and terrestrial sources. Additionally, the regular analysis of the chemical composition of rainwater at our location allows for an understanding of the significance of a single extreme weather event in the context of annual wet depositional patterns.

\section{Methods}

\subsection{Sample collection}

The rain sampling site used in this study was an open area of longleaf pine, wire grass, and turkey oak on the campus of the University of North Carolina at Wilmington $\left(34^{\circ} 13.9^{\prime} \mathrm{N}\right.$, $77^{\circ} 52.7^{\prime} \mathrm{W}, 8.5 \mathrm{~km}$ from the Atlantic Ocean). All rainwater event samples were collected using an Aerochem Metrics (ACM) Model 301 Automatic Sensing Wet/Dry Precipitation Collector which housed a $4 \mathrm{~L}$ glass beaker placed within a HDPE plastic bucket. All glassware used in this study for sample collection, filtration and storage was rinsed copiously with deionized water to remove salts and then heated at $450{ }^{\circ} \mathrm{C}$ in a muffle furnace for a minimum of 4 hours to remove organics prior to use.

Hurricane Irene made landfall on the Outer Banks of North Carolina on 27 August 2011 as a Category 1 hurricane. Rain from the storm began the morning of 26 August in Wilmington, NC, approximately $200 \mathrm{~km}$ south of where the storm made landfall. From the time rain started until the storm had passed, rain was collected periodically (every 2 to $5 \mathrm{~h}$ ) for a total of 11 individual samples and a total of over $200 \mathrm{~mm}$ of rain. Early samples $(\mathrm{A}-\mathrm{C})$ were collected for three distinct rain bands at the onset of the storm and later samples were collected when rain was continuous. Samples were analyzed immediately upon collection for hydrogen peroxide and $\mathrm{pH}$. Rainwater was filtered $(0.2-\mu \mathrm{m}$ pore size, polysulfone) and
$100 \mu \mathrm{L}$ of $6 \mathrm{M} \mathrm{HCl}$ was added to a $40-\mathrm{mL}$ filtered aliquot for DOC analysis. Anion samples were unfiltered and stored at $4{ }^{\circ} \mathrm{C}$ until analysis. Samples for all other analyses were filtered and stored at $4{ }^{\circ} \mathrm{C}$ in combusted glass vials until analysis could be carried out.

\subsection{Chemical analysis}

\subsection{1 pH}

Rainwater $\mathrm{pH}$ was measured using a Ross electrode calibrated with low ionic strength buffer with $\mathrm{pH}$ of 4.10 and 6.97. Ionic strength adjuster (pHix Orion Research Incorporated, Boston, Massachusetts) was added to each sample to match the ionic strength of samples to that of buffers. Measurements were $\pm 0.01 \mathrm{pH}$ units in the $\mathrm{pH} 4$ range and \pm 0.03 for samples with $\mathrm{pH} 5$ or above.

\subsubsection{Hydrogen peroxide}

Hydrogen peroxide $\left(\mathrm{H}_{2} \mathrm{O}_{2}\right)$ was analyzed using a fluorescence decay technique involving the peroxidase-mediated oxidation of the fluorophore scopoletin by $\mathrm{H}_{2} \mathrm{O}_{2}$ in rain and buffered at a pH of 7 with a phosphate buffer (Kieber and Helz, 1986). Fluorescence measurements were made on a Turner Designs (Sunnyvale, CA) Model 7200-000 fluorometer equipped with a $\mathrm{H}_{2} \mathrm{O}_{2}$ module wavelength filter $\left(\lambda_{\mathrm{ex}}=365 \pm 10 \mathrm{~nm}, \lambda_{\mathrm{em}}=486 \pm 10 \mathrm{~nm}\right)$. Calibration curves were obtained by preparing standards in ultrapure water (Milli-Q). $\mathrm{H}_{2} \mathrm{O}_{2}$ standard solutions were prepared fresh from a stock solution of $0.1 \mathrm{M} \mathrm{H}_{2} \mathrm{O}_{2}$, which had been standardized by titration with phenylarsine oxide. The method has an analytical precision of $2 \%$ relative standard deviation (\% RSD) at ambient rainwater concentrations (Kieber and Helz, 1986). All samples were analyzed in triplicate for $\mathrm{H}_{2} \mathrm{O}_{2}$.

\subsubsection{Anions and cations}

Anions $\left(\mathrm{Cl}^{-}, \mathrm{NO}_{3}^{-}\right.$, and $\left.\mathrm{SO}_{4}^{2-}\right)$ were measured with suppressed ion chromatography using a Dionex IC system outfitted with an IonPac®AS14A column and ASRS 300 4-mm suppressor. Standards were prepared from the sodium salts of each anion in ultrapure water (Milli-Q). Anions measurements had a RSD $\leq 5 \%$.

Analysis of cations $\left(\mathrm{Na}^{+}, \mathrm{Mg}^{2+}, \mathrm{K}^{+}\right.$and $\left.\mathrm{Ca}^{2+}\right)$ was performed under standard inductively coupled plasma (ICP) conditions with a PerkinElmer Model Optima 2100 DV Optical Emission Spectrometer. Samples were acidified to $2 \%$ with trace metal grade nitric acid and were allowed to come to room temperature before analysis. A standard curve for each metal was constructed using standards prepared in $2 \%$ nitric acid from commercially available ICP stock solutions of $\mathrm{Na}^{+}, \mathrm{Mg}^{2+}, \mathrm{K}^{+}$and $\mathrm{Ca}^{2+}$ (Clåritas). Absorbance was analyzed at $589.592 \mathrm{~nm}$ for $\mathrm{Na}, 285.213 \mathrm{~nm}$ for $\mathrm{Mg}$, $766.490 \mathrm{~nm}$ for $\mathrm{K}$ and $317.933 \mathrm{~nm}$ for Ca. All ICP measurements had a RSD $\leq 3 \%$. 
Non-sea-salt sulfate (NSS) was calculated, assuming a constant seawater ratio of $\mathrm{SO}_{4}^{2-}$ to $\mathrm{Na}^{+}$of 0.0601 to find sea-salt sulfate and subtracting this value from the total concentration of sulfate. Sodium data was not available for nonhurricane rain samples in 2011 so NSS was determined assuming a constant ratio of $\mathrm{SO}_{4}^{2-}$ to $\mathrm{Cl}^{-}$of 0.0517 . Previous work at our coastal site has demonstrated using either $\mathrm{Na}^{+}$ or $\mathrm{Cl}^{-}$as the proxy for sea salt yields results that are within $1 \%$ of each other (Willey and Kiefer, 1990), less than the analytical precision of the method.

\subsubsection{Ammonium}

Ammonium $\left(\mathrm{NH}_{4}^{+}\right)$analysis was carried out using a modified version of a fluorometric method (Holmes et al., 1999) in which o-phthaldialdehyde (OPA) reacts with ammonia to form a fluorescent chromaphore. The working reagent was prepared by adding $50 \mathrm{~mL}$ of an acetonitrile solution containing $2.0 \mathrm{~g}$ OPA to $1 \mathrm{~L}$ of a $0.1 \mathrm{M}$ borate buffer solution containing $0.3 \mathrm{mM}$ sulfite (to suppress reaction of OPA with free amino acids). The working reagent was stored in the dark for $24 \mathrm{~h}$ prior to use. Standards were prepared in ultrapure water (Milli-Q) with $\mathrm{NH}_{4} \mathrm{Cl}$. Analysis was carried out on filtered rainwater samples that had been stored in combusted glass containers at $4{ }^{\circ} \mathrm{C}$ for no more than one week at the time of analysis. $1.5 \mathrm{~mL}$ of samples and standards were combined with $5 \mathrm{~mL}$ of the working reagent in Nalgene HPDE sample vials and allowed to react in the dark for 3 hours. Fluorescence measurements were made on a Turner Designs (Sunnyvale, CA) Model 7200-000 fluorometer equipped with a wavelength filter $\left(\lambda_{\mathrm{ex}}=365 \pm 10 \mathrm{~nm}, \lambda_{\mathrm{em}}=430 \pm 10 \mathrm{~nm}\right)$. Each sample and standard was carried out in triplicate. Samples were analyzed without working reagent and with standard additions to correct for background fluorescence and matrix effects, respectively. The detection limit for $\mathrm{NH}_{4}^{+}$in rain by this method is $0.17 \mu \mathrm{M}$ (Kieber et al., 2005).

\subsubsection{Dissolved organic carbon}

Dissolved organic carbon (DOC) was determined by high temperature combustion (HTC) using a Shimadzu TOC 5000 total organic carbon analyzer equipped with an ASI 5000 autosampler. Standards were prepared from potassium hydrogen phthalate (KHP) in Milli-Q $\mathrm{H}_{2} \mathrm{O}$. Each sample was injected 4 times with a relative standard deviation (RSD) $\leq 3 \%$. The detection limit for this instrument is $4 \mu \mathrm{M}$ DOC.

\subsection{Back trajectories and supporting meteorological data}

Modeled back trajectories (Draxler and Rolph, 2012) were used to track the history of the air parcel over Wilmington at the time of sample collection. Trajectories were calculated for the $24 \mathrm{~h}$ preceding each sample collection for the air parcel at an elevation of $500 \mathrm{~m}$ over our sampling location. This elevation was selected as an approximation for the
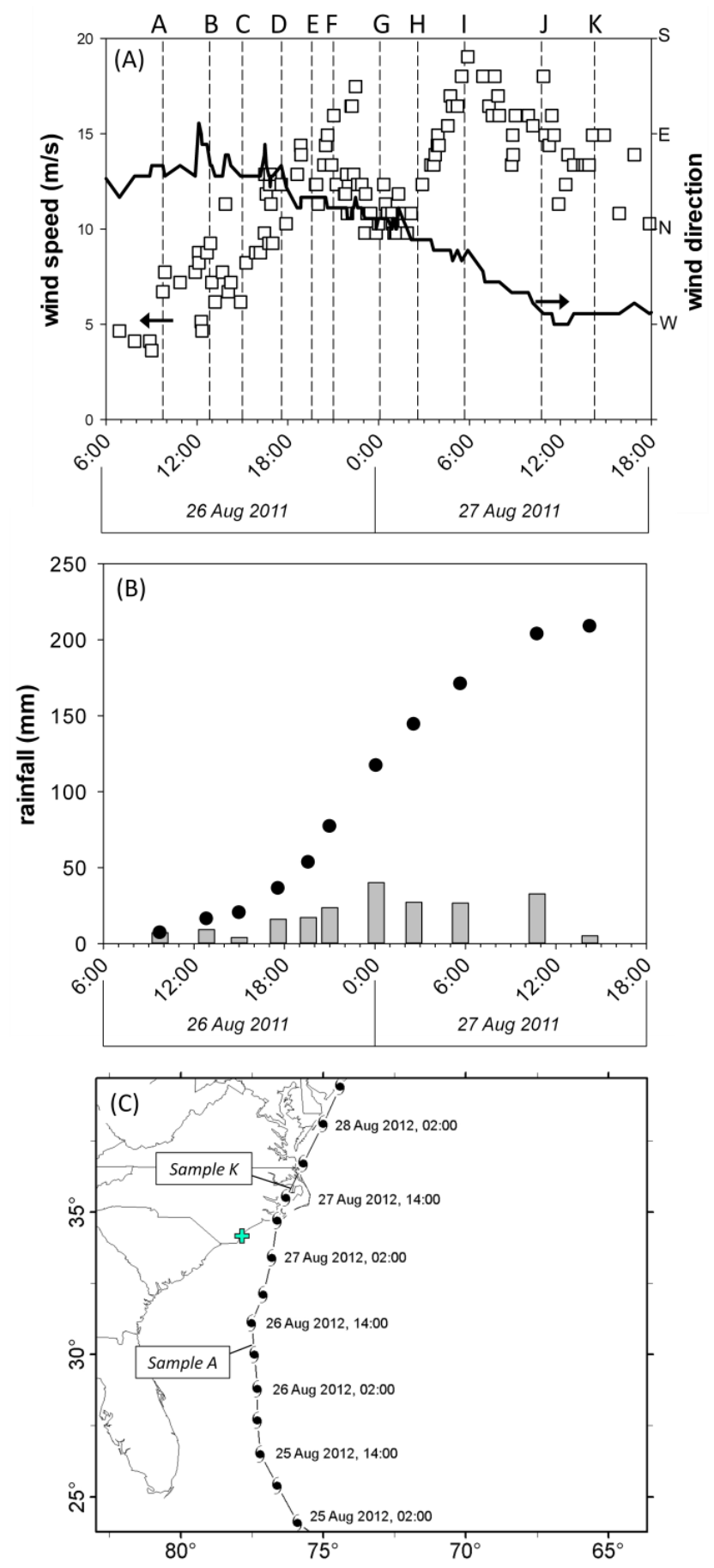

Fig. 1. (A) Plot of wind speed (open symbols) and direction (solid line) throughout Hurricane Irene. Vertical dashed lines indicate the collection time of rainwater. (B) Cumulative rain collected (points) versus time. Bars represent the amount of rain in each sample. (C) Track of Hurricane Irene with time of first (Sample A) and last (Sample K) rainwater collection indicated. The sampling location is indicated by "+" symbol. 

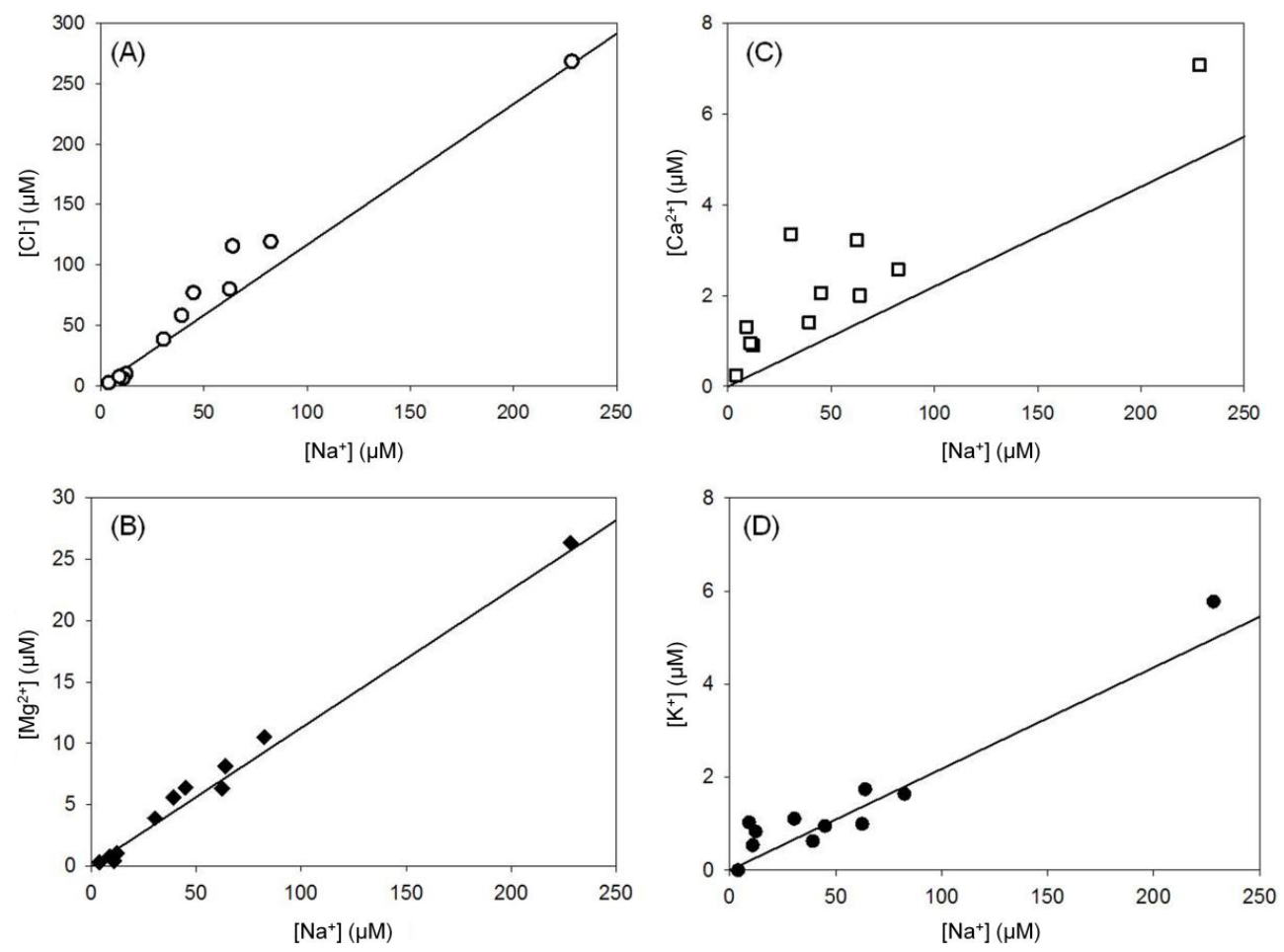

Fig. 2. Relationship between $(\mathbf{A}) \mathrm{Cl}^{-},(\mathbf{B}) \mathrm{Mg}^{2+},(\mathbf{C}) \mathrm{Ca}^{2+}$ and (D) $\mathrm{K}^{+}$with $\mathrm{Na}^{+}$. Solid lines represent molar ratios in sea salt.

well-mixed boundary layer from which precipitation originated (Walker et al., 2000; Kieber et al., 2005; Miller et al., 2008). Supporting meteorological data was obtained from an Automated Surface Observation System (ASOS) at Wilmington International Airport, which is located less than $5 \mathrm{~km}$ from our study site. Wind speed and direction data were retrieved from Weather Underground (wunderground.com) and are shown in Fig. 1a for the time period of interest. The track of Hurricane Irene was obtained from the National Hurricane Center's GIS archive (Fig. 1c, www.nhc.noaa.gov/gis).

\section{Results}

Over $200 \mathrm{~mm}$ of rain was sampled throughout Hurricane Irene for a total of 11 samples (Fig. 1). This volume of rainwater represents $16 \%$ of the total annual precipitation experienced at this site in 2011 . The results of all chemical analyses for each sample sequentially labeled A-K are presented in Table 1. Rainfall intensity for each sample was calculated by dividing the rainfall amount by the duration of rain for each sample. The duration of rain was either observed or, when rain was continuous, was the amount of time since the previous sample was collected. Wind direction, wind speed, total rain accumulation throughout the time course of the storm as well as the storm track is presented in Fig. 1. Easterly winds predominated early in the storm with a shift towards the west later in the event with sustained winds generally less than $20 \mathrm{~m} \mathrm{~s}^{-1}$ throughout the storm. Four different patterns of variation in the concentrations of rainwater components were observed during Hurricane Irene depending upon the origin of the analytes.

\subsection{Major ions from sea salt}

Concentrations of $\mathrm{Cl}^{-}, \mathrm{Mg}^{2+}, \mathrm{K}^{+}$and $\mathrm{Ca}^{2+}$ were compared to the concentration of $\mathrm{Na}^{+}$in each sample collected during Hurricane Irene to determine if they originated from sea spray. The molar ratio of $\mathrm{Cl}^{-}$to $\mathrm{Na}^{+}$for these samples (Fig. 2a) was close to that in seawater (1.165) which has been observed previously at this (Willey and Kiefer, 1993) and other (Sakihama and Tokuyama, 2005) coastal locations. The slight excess of $\mathrm{Cl}^{-}$relative to what would be expected from sea salt in some samples (as indicated by the points that lie above the line in Fig. 2a) indicates there are additional sources of chloride such as the scavenging of gas phase $\mathrm{HCl}$ (Keene et al., 1986). The $\mathrm{Mg}^{2+}$ and $\mathrm{K}^{+}$to $\mathrm{Na}^{+}$ratios indicated a sea salt source of these ions as well (Fig. 2b and d). The data comparing concentrations of $\mathrm{Ca}^{2+}$ to $\mathrm{Na}^{+}$were less clear as $\mathrm{Ca}^{2+}$ levels were higher than would be predicted from a unique sea salt source as evidenced by the predominance of data above the line representing the Ca:Na ratio in sea salt (Fig. 2c). The data presented in Fig. 2c suggest that there are significant additional sources of $\mathrm{Ca}^{2+}$ to rainwater at this location during tropical events, perhaps suspension of $\mathrm{CaCO}_{3}$-containing soils into the air during periods of high 
Table 1. Summary of data for samples collected throughout Hurricane Irene (26-27 August 2011). All concentrations are reported in mg L ${ }^{-1}$. (NA = not analyzed).

\begin{tabular}{rrrrrrrrrrrrrrr}
\hline Sample & $\begin{array}{r}\text { Collection } \\
\text { time }\end{array}$ & $\begin{array}{r}\text { Amount } \\
(\mathrm{mm})\end{array}$ & $\begin{array}{r}\text { Rainfall intensity } \\
\left(\mathrm{mm} \mathrm{h}^{-1}\right)\end{array}$ & $\mathrm{pH}$ & $\mathrm{H}_{2} \mathrm{O}_{2}$ & $\mathrm{DOC}$ & $\mathrm{Cl}^{-}$ & $\mathrm{NO}_{3}^{-}$ & $\mathrm{SO}_{4}^{2-}$ & $\mathrm{Na}^{+}$ & $\mathrm{Mg}^{2+}$ & $\mathrm{K}^{+}$ & $\mathrm{Ca}^{2+}$ & $\mathrm{NH}_{4}^{+}$ \\
\hline $\mathrm{A}$ & $08: 00-09: 45$ & 7.1 & 7.7 & 5.39 & 0.40 & 0.05 & 2.83 & 0.17 & 0.47 & 1.4 & 0.15 & 0.039 & 0.13 & 0.0075 \\
$\mathrm{~B}$ & $09: 45-12: 50$ & 9.1 & 11.0 & 5.28 & 0.41 & 0.11 & 2.73 & 0.14 & 0.44 & 1.0 & 0.16 & 0.037 & 0.083 & 0.012 \\
$\mathrm{C}$ & $12: 50-15: 00$ & 4.1 & 2.7 & 4.94 & 0.65 & 0.21 & 9.52 & 0.28 & 1.7 & 5.2 & 0.64 & 0.23 & 0.28 & 0.026 \\
$\mathrm{D}$ & $15: 00-17: 35$ & 16.0 & 8.3 & 5.30 & 0.14 & $<0.04$ & 4.22 & 0.037 & 0.57 & 1.9 & 0.26 & 0.064 & 0.10 & $<0.003$ \\
$\mathrm{E}$ & $17: 35-19: 35$ & 17.2 & 8.6 & 5.43 & 0.038 & $<0.04$ & 2.06 & 0.029 & 0.29 & 0.90 & 0.14 & 0.024 & 0.056 & $<0.003$ \\
F & $19: 35-21: 00$ & 23.6 & 16.6 & 5.43 & 0.040 & $<0.04$ & 0.087 & 0.014 & 0.034 & 0.088 & 0.0080 & $<0.004$ & 0.010 & $<0.003$ \\
$\mathrm{G}$ & $21: 00-00: 05$ & 40.1 & 13.0 & 5.66 & 0.032 & 0.18 & 1.36 & 0.052 & 0.20 & 0.70 & 0.095 & 0.043 & 0.13 & 0.012 \\
$\mathrm{H}$ & $00: 05-02: 35$ & 27.2 & 10.9 & 5.86 & 0.046 & 0.19 & 4.09 & 0.050 & 0.63 & 1.5 & 0.20 & 0.068 & 0.080 & 0.019 \\
I & $02: 45-05: 40$ & 26.7 & 8.7 & 5.71 & 0.040 & 0.40 & 0.348 & 0.056 & 0.075 & 0.28 & 0.026 & 0.033 & 0.036 & 0.051 \\
J & $05: 45-10: 45$ & 32.8 & 6.5 & 5.28 & 0.024 & NA & 0.208 & 0.048 & 0.26 & 0.25 & 0.011 & 0.021 & 0.038 & 0.083 \\
K & $10: 45-14: 15$ & 5.1 & 1.6 & 5.25 & 0.19 & 1.48 & 0.262 & 0.16 & 0.24 & 0.21 & 0.019 & 0.040 & 0.052 & 0.12 \\
\hline
\end{tabular}
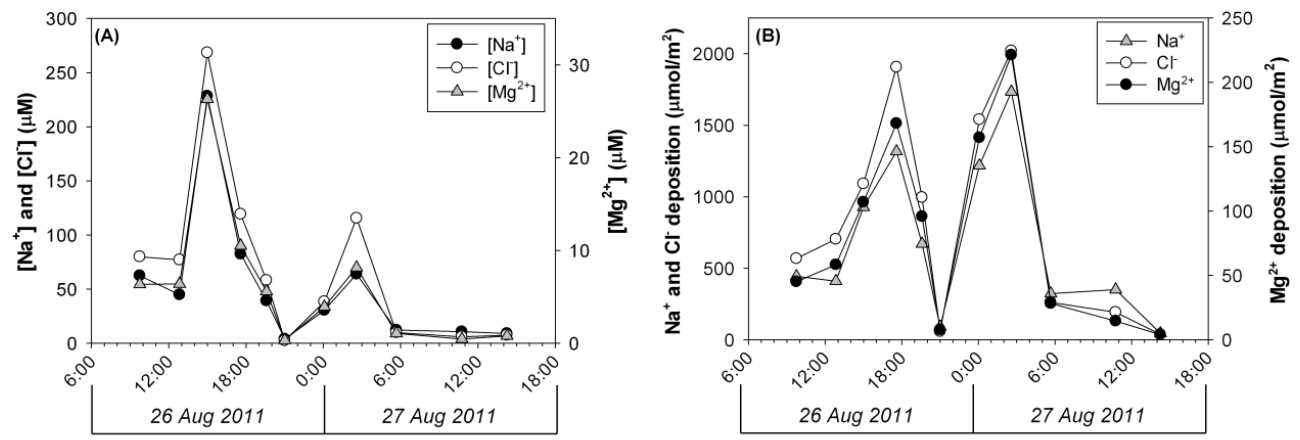

Fig. 3. (A) Concentrations and (B) depositions of sea-salt components $\mathrm{Na}^{+}, \mathrm{Cl}^{-}$and $\mathrm{Mg}^{2+}$ throughout Hurricane Irene.

wind. Cluster analysis of rainwater composition at this location previously indicated that calcium concentrations were more closely associated with agricultural activities than with sea salt (Willey and Kiefer, 1993).

The concentrations and depositions of sea-salt components in rain were highly variable throughout the hurricane, with two distinct maxima during the sampling regime (Fig. 3a). There was, however, no correlation between any sea-salt concentrations and either rainfall rate or wind speed $(0.124 \leq p \leq 0.450)$. A correlation with wind speed was observed in typhoon rain in Okinawa, Japan, by Sakihama and Tokuyama (2005). An initial increase in sea-salt deposition through the first maximum at sample $\mathrm{C}$ was followed by a decrease to minimum concentration and deposition in sample F. Increased sea-salt concentrations were again observed in samples $\mathrm{G}$ and $\mathrm{H}$ with lower concentrations occurring in the last three samples analyzed. The total deposition of chloride during the storm was significant in the context of annual wet deposition with Hurricane Irene accounting for $18 \%$ of the total wet deposition of $\mathrm{Cl}^{-}$at this location in 2011.

\subsection{Dissolved organic carbon and ammonium from terrestrial sources}

The patterns of DOC and $\mathrm{NH}_{4}^{+}$concentrations throughout the hurricane were similar to each other, but do not resemble the pattern seen for sea-salt components (Fig. 4a). DOC and $\mathrm{NH}_{4}^{+}$concentrations were low $(<20 \mu \mathrm{M}$ DOC and $<1.5 \mu \mathrm{M}$ $\mathrm{NH}_{4}^{+}$) in the samples collected early and in the middle of the storm while later samples had a marked increase in concentration for both analytes. The high concentrations of these analytes combined with the high volume of rain collected in later samples (Fig. 1b) resulted in the majority of the DOC and ammonium depositions occurring later in the storm (Fig. 4b). This pattern suggests DOC and $\mathrm{NH}_{4}^{+}$have similar, primarily nonmarine sources (Kieber et al., 2005; Willey et al., 2000).

\subsection{Nitrate, non-sea-salt sulfate and $\mathrm{H}^{+}$from anthropogenic sources}

The concentrations of nitrate $\left(\mathrm{NO}_{3}^{-}\right)$, non-sea-salt sulfate (NSS) and the $\mathrm{H}^{+}$ion were all extremely low compared with more typical Wilmington rainwater (Table 2 and Willey et al., 2006). These concentrations were lowest in midstorm samples with higher concentrations being detected at 

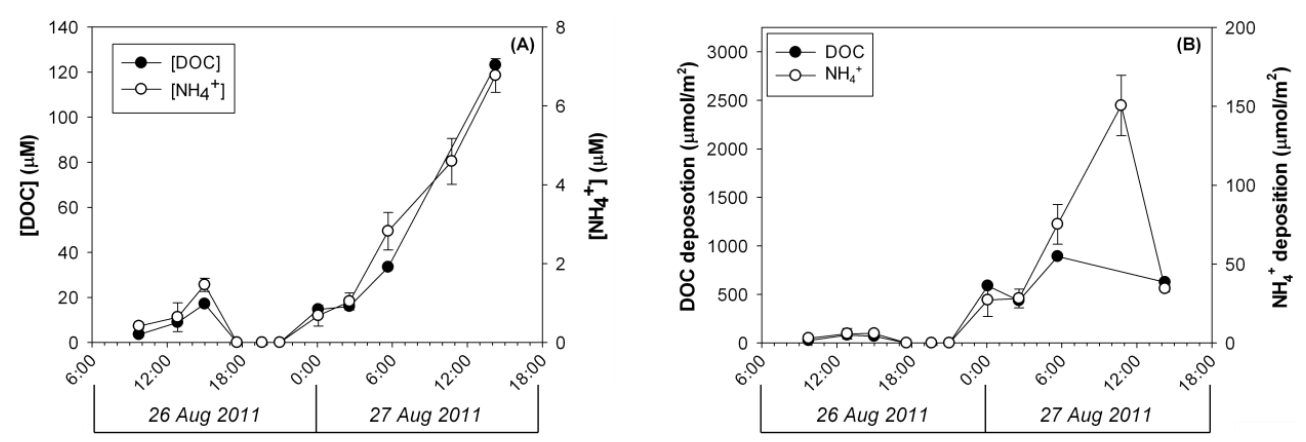

Fig. 4. (A) Concentrations and (B) depositions of DOC and $\mathrm{NH}_{4}^{+}$in rainwater collected throughout Hurricane Irene. The error bars for the $\mathrm{NH}_{4}^{+}$points represent the standard deviation of triplicate measurements. Sample J was not analyzed for DOC.
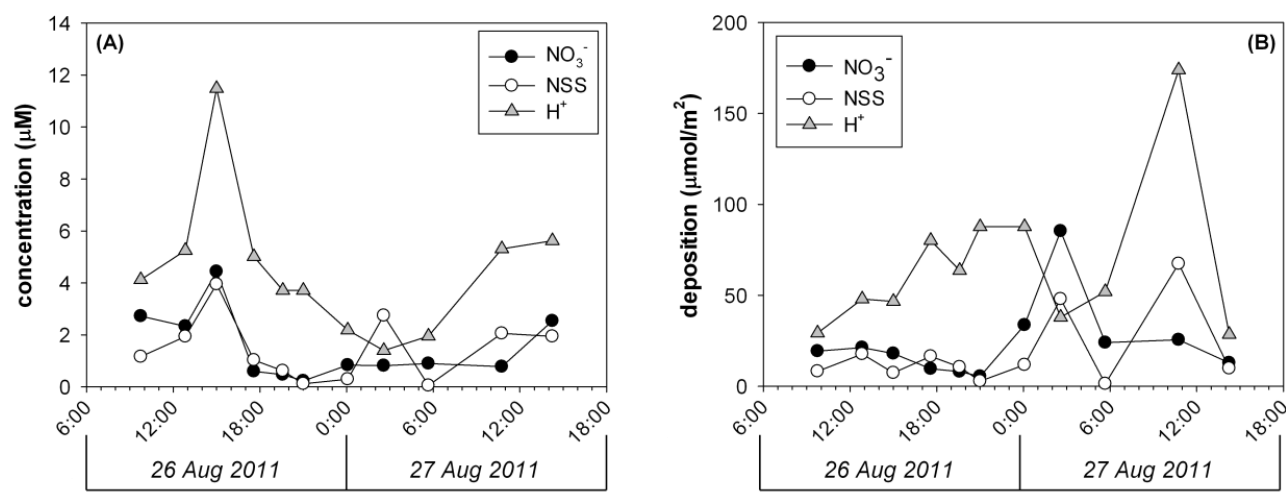

Fig. 5. (A) Concentrations and (B) depositions of $\mathrm{NO}_{3}^{-}$, NSS and $\mathrm{H}^{+}$ion throughout Hurricane Irene.

the beginning (samples A-C) and end (samples J and/or K) of the storm (Fig. 5a). With the exception of sample H for NSS, the similar pattern of changing concentrations for $\mathrm{NO}_{3}^{-}$, NSS and $\mathrm{H}^{+}$during Hurricane Irene is consistent with the observation that these analytes are generally positively correlated in rainwater $(n=11, r>0.70, p<0.02$ for all correlations in this study, Willey and Kiefer, 1993; Hooper and Peters, 1989). $\mathrm{NO}_{3}^{-}$and NSS are both formed as their corresponding acids $\left(\mathrm{HNO}_{3}\right.$ and $\left.\mathrm{H}_{2} \mathrm{SO}_{4}\right)$ upon oxidation of $\mathrm{NO}_{x}$ and $\mathrm{SO}_{2}$, respectively, that are both emitted from combustion processes (Calvert et al., 1985).

\subsection{Hydrogen peroxide from photochemical production}

The highest concentrations and deposition of $\mathrm{H}_{2} \mathrm{O}_{2}$ were observed in samples A-C collected early in the storm during the daylight hours of 26 August (Fig. 6). The peak $\mathrm{H}_{2} \mathrm{O}_{2}$ concentration in sample $\mathrm{C}$ is likely a result of the low volume of rain obtained during this period, as indicated by the peak deposition occurring in sample $\mathrm{B}$. The higher $\mathrm{H}_{2} \mathrm{O}_{2}$ concentrations recorded for samples collected during the peak sunlight intensity daylight hours is similar to the pattern observed for hydrogen peroxide in non-tropical events measured at this location during the summer (Avery et al., 2001) and are most likely due to photochemical generation of $\mathrm{H}_{2} \mathrm{O}_{2}$ in the gas phase from hydroperoxy radicals, which are subsequently scavenged into the aqueous phase as rain (Gunz and Hoffmann, 1990; Moller, 2009). Concentrations decreased to below $1.5 \mu \mathrm{M}$ for much of the remaining duration of the storm, which occurred throughout the night and morning of $27 \mathrm{Au}$ gust. The concentration of $\mathrm{H}_{2} \mathrm{O}_{2}$ did not change until last sample (K) was collected in the afternoon of 27 August, but this was likely driven by the low sample volume, as indicated by the low deposition throughout the storm (Fig. 6b). The last sample collected during the daylight hours of 27 August increased to $5 \mu \mathrm{M}$ most likely due to in situ photochemical production of $\mathrm{H}_{2} \mathrm{O}_{2}$ (Kieber et al., 2010).

\section{Discussion}

Hurricane Irene generated tropical force winds extending over a diameter of about $840 \mathrm{~km}$ and the eye of the storm was about $130 \mathrm{~km}$ away from our sampling location at its closest point. Wilmington, NC experienced peak wind gusts of $30 \mathrm{~m} \mathrm{~s}^{-1}\left(65 \mathrm{milh}^{-1}\right)$ on the morning of $27 \mathrm{Au}-$ gust 2011. Changes in air parcel origin and elevation as well as wind speed and direction experienced in Wilmington throughout Hurricane Irene allowed for an evaluation of how these physical factors influence the composition of rainwater 
Table 2. Contribution of Hurricane Irene to the annual wet deposition of various species at this location. Volume weighted average (VWA) concentrations for non-hurricane $(N=88)$ and Hurricane Irene samples are in $\mu \mathrm{M}$. When concentrations were non-detectable (samples $\mathrm{D}-\mathrm{F}$ for DOC and $\mathrm{NH}_{4}^{+}$), concentrations were assumed to be half the detection limit (Table 1).

\begin{tabular}{lrrr}
\hline & $\begin{array}{r}\text { \% annual wet } \\
\text { deposition from } \\
\text { Hurricane Irene }\end{array}$ & $\begin{array}{r}\text { VWA concentrations } \\
\text { in Hurricane } \\
\text { Irene rainwater }\end{array}$ & $\begin{array}{r}\text { VWA concentrations } \\
\text { for non-hurricane } \\
2011 \text { rainwater }\end{array}$ \\
\hline $\mathrm{H}^{+}$ & $3.4 \%$ & 3.5 & 19 \\
$\mathrm{H}_{2} \mathrm{O}_{2}$ & $2.3 \%$ & 2.6 & 22 \\
$\mathrm{DOC}^{-}$ & $3.1 \%$ & 16 & 95 \\
$\mathrm{Cl}^{-}$ & $18 \%$ & 50 & 31 \\
$\mathrm{NO}_{3}^{-}$ & $1.5 \%$ & 0.96 & 12 \\
$\mathrm{NSS}^{-}$ & $3.0 \%$ & 1.1 & 7.0 \\
$\mathrm{NH}_{4}^{+}$ & $2.6 \%$ & 1.6 & $10.1^{*}$ \\
Volume & $16 \%$ & $210 \mathrm{~mm}$ & $8.5 \mathrm{~mm}$ \\
\hline
\end{tabular}

* Annual data were not available for $\mathrm{NH}_{4}^{+}$in 2011 so the value reported is from annual VWA reported for this location in Kieber et al. (2005).

throughout a single extreme weather event. The 24-h back trajectories for air at an elevation of $500 \mathrm{~m}$ over Wilmington at the time of each sample collection are presented in Fig. 7. The air parcel origin (Fig. 7e) was marine initially (samples A-H) with an increase in terrestrial influences with shifting wind direction as the storm passed by the region (samples I-K). The vertical movement of the air parcel dipped to lower elevations followed by rapid vertical mixing (Fig. 7c) in the middle of the storm (samples G-H-I), whereas initial and ending samplings had back trajectories that consistently remained over $100 \mathrm{~m}$ above sea level in the $24 \mathrm{~h}$ preceding sample collection (Fig. 7a, b and d). The back trajectories and elevation changes of Hurricane Irene presented in Fig. 7 represent four distinct periods, which were used to interpret the compositional fluctuations observed in the sequential samples.

\subsection{Period I: early rain bands (samples A-C)}

The initial samples collected from distinct rain bands early in the storm were characterized by high sea-salt (Fig. 3) concentrations, which is consistent with samples collected at this site for non-hurricane rains of marine origin. Non-hurricane marine rains $(n=18)$ had a volume weighted average $\mathrm{Cl}^{-}$ concentration of $33.3 \mu \mathrm{M}$ at this location in 2011. The higher sea salt content of the early hurricane samples relative to typical marine storms is likely a result of increasing wind speed and wave action during this time that entrained high levels of sea-salt aerosols in the atmosphere (Sakihama and Tokuyama, 2005).

In addition to wind speed, total rain volume is an important factor to consider with regard to the concentration of sea salt in rainwater. The discontinuous rainfall during Period I resulted in a small total volume of rain during this time (Fig. 1b) and contributed to high sea-salt concentrations in samples $\mathrm{A}-\mathrm{C}$ with the highest concentrations recorded for the lowest volume sample $\mathrm{C}$ when the rainfall intensity was relatively low (Table 1). All other components $\left(\mathrm{H}^{+}, \mathrm{H}_{2} \mathrm{O}_{2}\right.$, DOC, $\mathrm{Ca}^{2+}, \mathrm{NH}_{4}^{+}, \mathrm{NO}_{3}^{-}$, and NSS) also had concentration maxima in sample $\mathrm{C}$, demonstrating the importance of rain volume in controlling concentrations of all components, regardless of origin.

Concentrations of other components, such as $\mathrm{NO}_{3}^{-}$and NSS, in samples collected during period I were typical of those recorded in other non-hurricane marine storms in 2011. The volume weighted averages of $\mathrm{NO}_{3}^{-}$and NSS in nonhurricane marine rain samples $(N=18)$ at our rain site in 2011 were $6.52 \mu \mathrm{M}$ and $2.85 \mu \mathrm{M}$, respectively. This suggests that levels of $\mathrm{NO}_{3}^{-}$and NSS recorded in the first three samples of Hurricane Irene are typical of what is observed at our location during non-hurricane marine rain events and these initial samples likely represent removal of water-soluble aerosols from the troposphere by rainfall.

\subsection{Period II: dilution (samples D-F)}

Wind speed increased and rainfall became continuous as our sampling campaign continued (Fig. 1a). Despite a previous report of wind speed and sea-salt concentration being positively correlated in typhoon rains (Sakihama and Tokuyama, 2005), levels of sea salt $\left(\mathrm{Na}^{+}, \mathrm{Cl}^{-}, \mathrm{Mg}^{2+}, \mathrm{K}^{+}\right)$decreased from the maximum observed in sample $\mathrm{C}$ to a minimum concentration in sample $\mathrm{F}$ even though winds speeds during sampling $\mathrm{F}$ were approximately 3 times higher than during sampling C (Fig. 1a). We attribute the decrease in sea-salt concentrations during this second period of Hurricane Irene to the removal of sea-salt aerosols from the atmosphere as the total rain volume accumulates and relatively little change in the trajectory is observed. This interpretation is supported by the decreasing or non-detectable concentrations of all other analytes (DOC, $\mathrm{NH}_{4}^{+}, \mathrm{H}^{+}, \mathrm{H}_{2} \mathrm{O}_{2}, \mathrm{NO}_{3}^{-}$, NSS and $\mathrm{Ca}^{2+}$ ) during this period as well. 

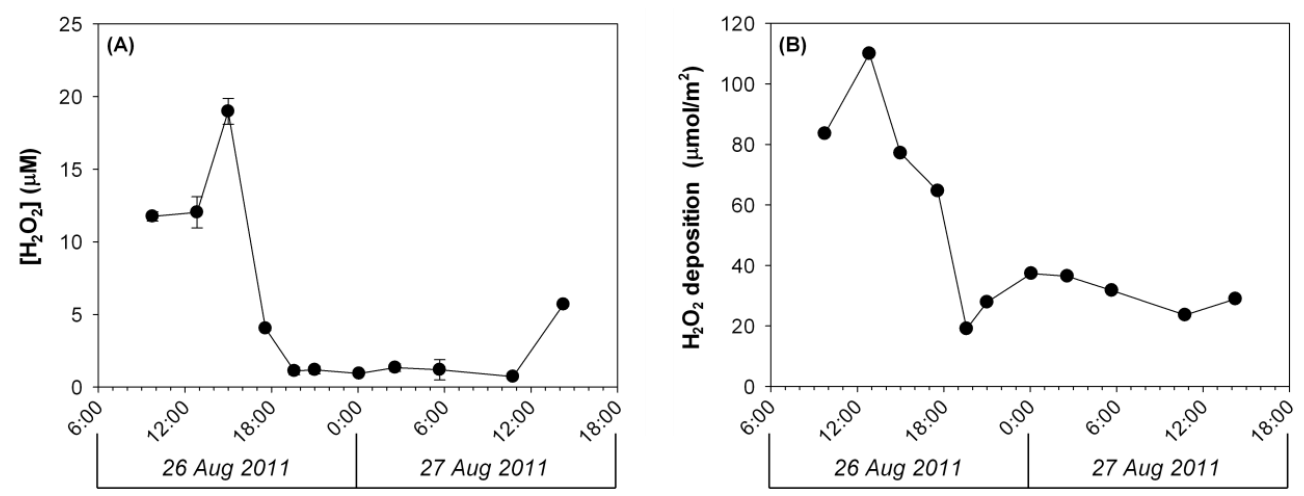

Fig. 6. (A) Concentration and (B) deposition of $\mathrm{H}_{2} \mathrm{O}_{2}$ throughout Hurricane Irene. Error bars represent the standard deviation of triplicate measurements.

\subsection{Period III: low elevation marine air parcel (samples $\mathbf{G}$ and $\mathbf{H}$ )}

There was an increase in sea-salt concentrations in samples $\mathrm{G}$ and $\mathrm{H}$ after the period of wash out. This sampling period also corresponds to when the eye of Hurricane Irene was closest to our sampling location (approximately $130 \mathrm{~km}$ away when sample $\mathrm{H}$ was collected, Fig. 7f). Back trajectories indicate the air over Wilmington at the time of these sample collections had previously been at low elevations $(<50 \mathrm{~m}$, Fig. 7c) over the ocean surface. When the air is close to the sea surface and then is lifted, sea salt again becomes entrained in rainwater. A similar effect was observed at this site during tropical storm Ernesto when $\mathrm{Cl}^{-}$ion increased mid-storm, eventually reaching a concentration over $1 \mathrm{mM}$ (Miller et al., 2008). Although sample I had a similar air elevation (Fig. 7d) to samples $\mathrm{G}$ and $\mathrm{H}$, the air parcel traveled over significantly more land before reaching Wilmington, so seasalts were washed out before reaching the sampling site. Components with predominately terrestrial sources (DOC, $\mathrm{NH}_{4}^{+}$, $\mathrm{NO}_{3}^{-}$, NSS) remained low or non-detectable during Period III as they had been washed out during Period II and the air parcel had not yet shifted to over land where their levels could be replenished.

\subsection{Period IV: terrestrial air parcel (samples I-K)}

The final samples collected in our campaign saw increasingly terrestrial influences as winds shifted to out of the north and west (Fig. 7). This was reflected in the composition of samples with increased concentrations of DOC, $\mathrm{NH}_{4}^{+}$, NSS, $\mathrm{NO}_{3}^{-}$and $\mathrm{H}^{+}$(Figs. 4 and 5) as sea-salt components were again diminished (Fig. 3). DOC is higher in rainwater events with more terrestrial back trajectories because of additional natural and anthropogenic inputs of organic material into the atmosphere (Willey et al., 2000). Natural terrestrial sources of DOC may become increasingly significant during extreme weather events such as hurricanes when high wind speeds suspend soil or plant material in the air, resulting in DOC levels at the end of the storm that far exceed concentrations measured in earlier samples.

Ammonium concentrations during Hurricane Irene (Fig. 4) had a similar concentration profile as Hurricane Isabel when it passed by this location in 2003. High $\mathrm{NH}_{4}^{+}$ samples $(>4 \mu \mathrm{M})$ in the previous study had back trajectories like those of samples $\mathrm{J}$ and $\mathrm{K}$ (Fig. 7e). These higher $\mathrm{NH}_{4}^{+}$concentrations during the latter part of the sampling campaign can be attributed to the air parcels passing over a region with agricultural activities which is a major source of $\mathrm{NH}_{4}^{+}$to the atmosphere (Kieber et al., 2005). Specifically, the large swine population in North Carolina's Coastal Plain region where trajectories $\mathrm{J}$ and $\mathrm{K}$ passed directly through is a major local source of ammonium in rainwater (Walker et al., 2000).

Although NSS, $\mathrm{NO}_{3}^{-}$and $\mathrm{H}^{+}$increased at the end of the storm (Fig. 5), they did not greatly exceed levels experienced in Period I as was observed for DOC and $\mathrm{NH}_{4}^{+}$(Fig. 4). We suggest this is a result of the differences in the lifetime and source for these groups. After wash out during Period II NO and NSS most likely have not had time to be regenerated in the atmosphere even as trajectories shifted to terrestrial paths. Likewise, $\mathrm{H}_{2} \mathrm{O}_{2}$, which is photochemically generated in the atmosphere, shows only a slight increase in the final sample that was collected in the early afternoon of 27 August (Fig. 6). DOC and $\mathrm{NH}_{4}^{+}$, on the other hand, may be redeposited via rain in a state that is not chemically altered or geographically removed from their terrestrial sources.

\section{Implications}

Examining factors that influence compositional alterations of rainwater during tropical weather events is important because these systems can contribute large, episodically significant wet depositional fluxes of chemically divergent analytes in rainwater over relatively short timescales. Table 2 summarizes the contribution of Hurricane Irene to total annual wet deposition of all components for which annual data 

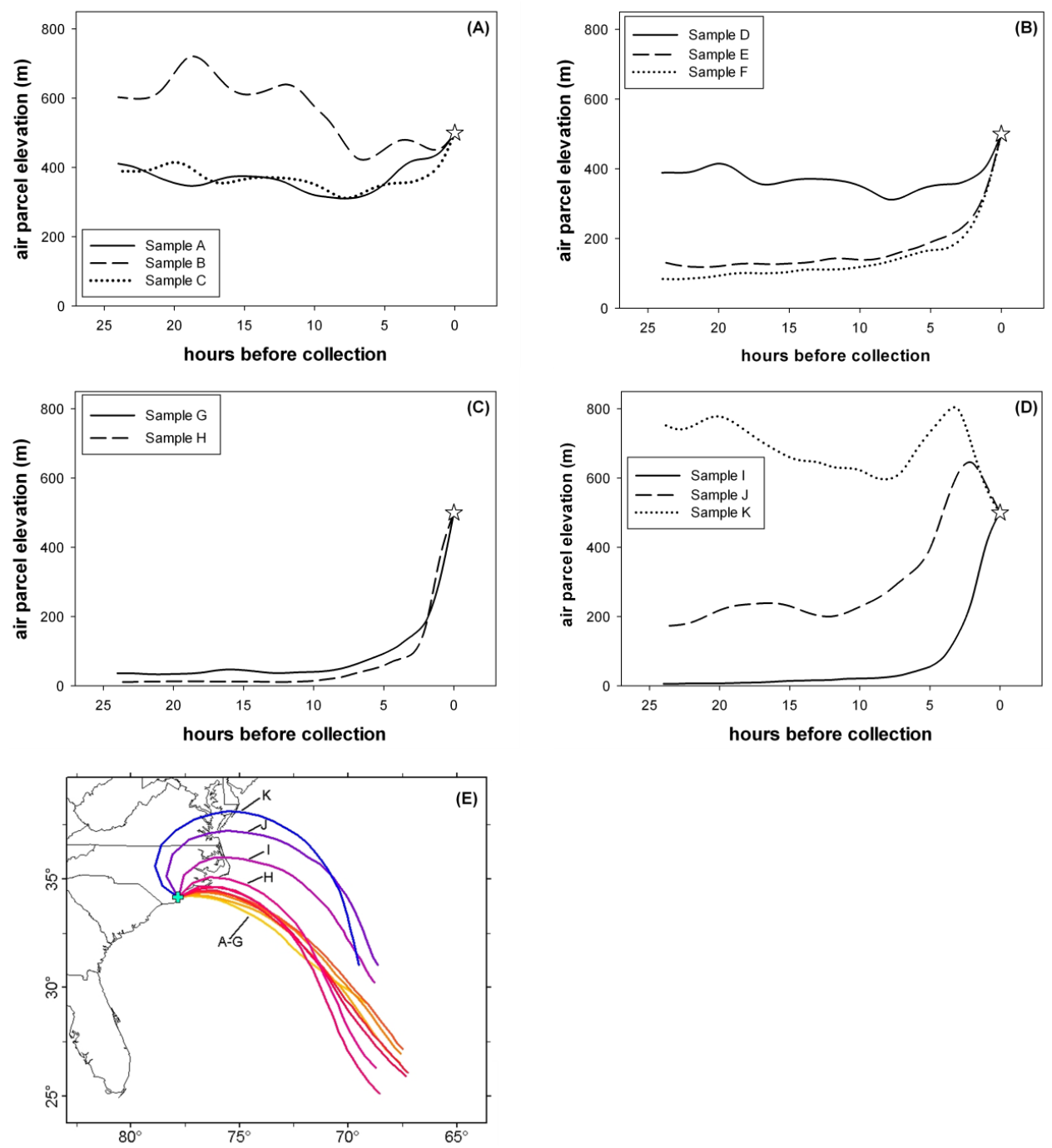

Fig. 7. Vertical movement of 500-m air parcel during the $24 \mathrm{~h}$ preceding sample collection for samples during (A) period I, (B) period II, (C) period III and (D) period IV. (E) Back trajectories at an elevation of $500 \mathrm{~m}$ for $24 \mathrm{~h}$ preceding each sample collection. The sampling location is indicated by "+" symbol.

is available. Most significant is the contribution by Hurricane Irene of $18 \%$ of the annual wet deposition of $\mathrm{Cl}^{-}$at this location. The annual contribution of other sea-salt components was likely just as considerable, but annual data for these species were not available. Even though this is a large percentage of the total, it is less than other hurricanes, which typically contribute approximately half of the annual chloride (Willey and Kiefer, 1993; Miller et al., 2008). The high volume of rainfall experienced during the hurricane resulted in total deposition of other rainwater components that was 1.4-3.9 times that of a typical rain event experienced at this location in 2011. The possible increase in severe storms due to climate change could mean the contribution of these large depositional events to annual wet depositional patterns may become more significant in the future.
The eleven sequential collections reported for Hurricane Irene represent the most detailed temporal analysis of rainwater during a tropical event to date. Hurricane Irene also presented a unique opportunity to understand the factors that drive compositional changes of rainwater throughout an extreme weather event. Parameters such as air parcel origin and elevation as well as wind speed influenced analyte concentrations, although the relative importance of these factors was a function of the source of analytes in rainwater. Total rain volume was an important variable for all components measured, regardless of source, but a simple washing out of rainwater constituents was not observed. This work underscores why analysis of one composite sample cannot capture the complexity of factors that influence compositional changes in rainwater during extreme weather events like Hurricane Irene. 
Acknowledgements. This work would not have been possible without the commitment of the following students who carried out timely sample collection and processing: Josh Humphreys, Stefanie Kinney Tatum, Briana Rice, Joanna Hamilton, Nikki Byrd, Brennan Opanasenko and Angela Carroll. UNCW campus police ensured the safety of all those involved. Steve Skrabal assisted with ICP analysis and Michael Rhode made the GIS maps (Figs. 1c and 7e). The authors gratefully acknowledge the NOAA Air Resources Laboratory (ARL) for the data from the HYSPLIT transport and dispersion model (http://www.arl.noaa.gov/ready.php). We also wish to thank the National Hurricane Center for information on Hurricane Irene's track (http://www.nhc.noaa.gov/gis/). This work was supported by NSF Atmospheric Chemistry Grant AGS 1003078 .

Edited by: J. G. Murphy

\section{References}

Avery, G. B., Willey, J. D., and Kieber, R. J.: Diurnal variations in major rainwater components at a coastal site in North Carolina, Atmos. Environ., 35, 3927-3933, 2001.

Avery, G. B., Willey, J. D., Kieber, R. J., Shank, G. C., and Whitehead, R. F.: Flux and bioavailability of Cape Fear River and rainwater dissolved organic carbon to Long Bay, souteastern United States, Global Biogeochem. Cy., 17, 1402-1407, 2003.

Avery, G. B., Kieber, R. J., Willey, J. D., Shank, G. C., and Whitehead, R. F.: Impact of hurricanes on the flux of rainwater and Cape Fear river water dissolved organic carbon to Long Bay, southeastern United States, Global Biogeochem. Cy., 18, 30153020, 2004.

Calvert, J. G., Lazarus, A., Kok, G. L., Heikes, B. G., Walega, J. G., Lind, J., and Cantrell, C. A.: Chemical mechanisms of acid generation in the troposphere, Nature, 317, 27-35, 1985.

Cheng, M. C. and You, C. F.: Sources of major ions and heavy metals in rainwater associated with typhoon events in southwestern Taiwan, J. Geochem. Expl., 105, 106-116, doi:10.1016/j.gexplo.2010.04.010, 2010.

Gunz, D. and Hoffmann, M. R.: Atmospheric chemistry of peroxides: A review, Atmospheric Environment, 24A, 1601-1633, 1990.

Holmes, R. M., Aminot, A., Kerouel, R., Hooker, B. A., and Peterson, B. J.: A simple and precise method for measuring ammonium in marine and freshwater ecosystems, Canad. J. Fish. Aquat. Sci., 56, 1801-1808, 1999.

Hooper, R. P., and Peters, N. E.: Use of multivariate analysis for determining sources of solutes found in wet atmospheric deposition in the United States, Environmental Science and Technology, 23, 1263-1268, 1989.
HYSPLIT (Hybrid Single Particle Langrangian Integrated Trajectory) Model access via NOAA ARL READY Website at: http:// ready.arl.noaa.gov/HYSPLIT.php (last access: 19 January 2012), NOAA Air Resources Laboratory, Silver Spring, MD, USA, 2012.

Keene, W. C., Pszenny, A. A. P., Galloway, J. N., and Hawley, M. E.: Sea-salt corrections and interpretation of constituent ratios in marine precipitation, J. Geophys. Res., 91, 6647-6658, 1986.

Kieber, R. J. and Helz, R. G.: Two method verification of hydrogen peroxide determinations in natural waters, Analyt. Chem., 58, 2312-2315, 1986.

Kieber, R. J., Long, M. S., and Willey, J. D.: Factors influencing nitrogen speciation in coastal rainwater, J. Atmos. Chem., 52, 81-99, 2005.

Kieber, R. J., Smith, J., Mullaugh, K. M., Southwell, M. W., Avery, G. B., and Willey, J. D.: Influence of dissolved organic carbon on photochemically mediated cycling of hydrogen peroxide in rainwater, J. Atmos. Chem., 64, 149-158, 2010.

Miller, C., Willey, J. D., and Kieber, R. J.: Changes in rainwater composition in Wilmington, $\mathrm{NC}$ during tropical storm Ernesto, Atmospheric Environment, 42, 846-855, doi:10.1016/j.atmosenv.2007.10.023, 2008.

Moller, D.: Atmospheric hydrogen peroxide: Evidence for aqueous phase formation from a historic perspective and a one year measurement campaign, Atmos. Environ., 43, 5293-5936, 2009.

Raymond, P. A.: The composition and transport of organic carbon in rainfall: Insights from the natural (C-13 and C14) isotopes of carbon, Geophys. Res. Lett., 32, 4, L14402, doi:10.1029/2005g1022879, 2005.

Sakihama, H. and Tokuyama, A.: Effect of typhoon on chemical composition of rainwater in Okinawa Island, Japan, Atmos. Environ., 39, 2879-2888, doi:10.1016/j.atmosenv.2004.12.043, 2005.

Walker, J. T., Aneja, V. P., and Dickey, D. A.: Atmospheric transport and deposition of ammonium in North Carolina, Atmos. Environ., 34, 3407-3418, 2000.

Willey, J. D. and Kiefer, R. H.: A contrast in winter rainwater composition: maritime versus continental rain in eastern North Carolina, Mon. Weather Rev., 118, 488-494, 1990.

Willey, J. D. and Kiefer, R. H.: Atmospheric deposition in southeastern North Carolina: Composition and quantity, J. Elisha Mitchell Sci. Soc., 109, 1-19, 1993.

Willey, J. D., Kieber, R. J., Eyman, M. S., and Avery, G. B.: Rainwater dissolved organic carbon: Concentrations and global flux, Global Biogeochem. Cy., 14, 139-148, 2000.

Willey, J. D., Kieber, R. J., and Avery, G. B.: Changing chemical composition of precipitation in Wilmington, North Carolina, USA: Implications for the continental USA, Environ. Sci. Technol., 40, 5675-5680, 2006. 